\title{
What Is 'Tenderpreneuring'? A Review of the Literature
}

\author{
Veronica Goitsemang Magang ${ }^{1} \&$ Tebogo Israel ‘Teddy' Magang ${ }^{2}$ \\ ${ }^{1}$ Department of Extra Mural Unit, Centre for Continuing Education, University of Botswana, Botswana \\ ${ }^{2}$ Department of Management, Faculty of Business, University of Botswana, Botswana \\ Correspondence: Tebogo Israel 'Teddy' Magang, Department of Management, Faculty of Business, University of \\ Botswana, Private Bag UB 0022, Gaborone, Botswana. E-mail: magangti@mopipi.ub.bw
}

Received: September 22, 2019

Accepted: November 7, 2019

Online Published: November 10, 2019

doi:10.5539/ijbm.v14n12p128

URL: https://doi.org/10.5539/ijbm.v14n12p128

\begin{abstract}
This paper theoretically attempts to examine a 'buzzword' which has been used to describe a system of awarding tenders [infamously referred to as 'tenderpreneuring'] in developing countries, by conducting a review of the literature on this practice. The paper endeavors to define 'tenderpreneuring' by examining literature, reports, opinion pieces etc on this practice which seems to be spreading rapidly in the public and private sectors in Botswana, South Africa, Kenya in particular. The paper also makes an effort to make a comparison between "tenderpreneuring' and the traditional form of tendering which follows best practice governance principles. An endeavor is also made to trace the roots of 'tenderpreneuring' and how 'tenderpreneuring' has the potential to negatively impact citizen economic empowerment. The paper further attempts to use the theory of accountability to demonstrate that where tendeperpreneuring is practiced, there are potential connotations of poor governance on the part of [government or private company] officers who award lucrative tenders to tenderpreneurs. The paper concludes by attempting to examine the possible ramifications of 'tenderpreneuring'. Consisely, it concludes that tenderpreneuring has the potential to condemn the society to poverty at both personal and national level and rob them of their respect and dignity.

The discussion from this paper has potential to conscientise policy decision makers on bad governance practices emanating from possibly crooked tendering processes both in the public and private sector under the code name 'tenderpreneuring'.
\end{abstract}

Keywords: tenderpreneuring, tendering, governance, accountability, citizen economic empowerment

\section{Introduction}

Tenderpreneuring has become a buzzword in some African countries in the past two decades more especially in South Africa, Kenya and more recently in Botswana. It is not clear where this word originated between South Africa and Kenya. Tenderpreneur is a portmanteau ${ }^{l}$ or combination of 'tendering' and 'entrepreneur'. A search on the internet yielded a variety of definitions from South Africa and Kenya.

In Kenya, a tenderprpeneur is defined in accordance with their personal characteristics and behavioral patterns. For instance, a tenderpreneur is defined as a young person, mostly male in his thirties who has made copious amounts of money from a government contract [such as the supply of biro pens or a consulting service of any kind], is the loudest in his group owing to his new 'success' [new money, nouveau riche], will not pass up a chance to introduce himself, and occasionally speaks about having meetings and or dinners with government dignitaries (Chege, 2018). He also speaks very loud on the phone more especially when discussing his next tender with a government official. According to Chege (2018), the tenderpreneur is also disrespectful to women and children as evidenced by his womanizing habits and fathering many children with different women (Chege, 2018). He also boasts a lot about his new found wealth on social media.

In South Africa, Piper and Chairman (2018) define 'Tenderpreneur' as "a South African colloquialism for a businessperson who uses political contacts to secure government procurement contracts (called 'tenders') often as part of reciprocal exchange of favours or benefits",1. According to the authors, 'tenderpreneurs' are associated with corruption, nepotism and clientelism because the award of many tenders is driven by informal interests and/or political affiliation, rather than the requirements of formal procedure. The origins of this term in South Africa date to the second black president of South Africa's era Mr. Thabo Mbeki (1999 - 2008) (Piper and Chairman (2018). The authors content that tenderpreneuring was associated with the advancement of black entrepreneurs who 
entered into the private business sector on a legitimate basis under the framework of state policies to enable the advancement of 'black designated groups' in commerce and industry during the era of President Thabo Mbeki (Piper and Chairman (2018). Also in South Africa, Marjawar (2017) defines tenderpreneurs as individuals with exceptional skills at bidding for government tenders.

The skill is not based on, "one's ability to respond to the laborious and detailed demands of a government request for tenders, but rather the connections [political] one has within the cartels in government procurement world to be able to swing a few of the lucrative tenders one's way and share the usually overpriced bill with the partners in crime within the government circles" (Marjawar, 2017).

The author opines that tenderpreneuring is a low investment venture which requires at the minimum, a cellular or mobile phone with calling credit. It is a high risk high return industry which has produced briefcase millionaires within a short period of time (Majawar, 2017). While it creates millionaires overnight, the overall loser in the industry is the general public who are the [supposed] beneficiaries of projects undertaken by tenderpreneurs. Tenderpreneuring is associated with instant wealth and riches and depicts opulence, 'glitz and glamour' that is attractive to the eye but sadly short-lived.

In Botswana, not much has been written about 'tenderpreneuring'. However, anecdotal evidence from numerous training seminars conducted by the researchers between 2012 and 2018 on corporate governance among both government and private sector officials indicates that the cancer of tenderpreneuring is quite prevalent in the country. For instance, in Botswana officials responsible for awarding tenders always insist on wanting, "go jesiwa sengwenyana" by the winner of the tender. Loosely translated, "go jesiwa" in English means to be given something to eat, while "sengwenyana" refers to something. Therefore the phrase "go jesiwa sengwenyana" in the context of awarding tenders means that officials in Botswana [government or private] always want the winner of the tender to give them something [in pecuniary/monetary terms as payment/reward] because they have awarded him/her the tender. Clearly, if the tenderer is not willing to give the officials something, he/she will not be favoured by the officials. In a way, for one to win a government tender or any tender for that matter, they should be willing to pay a certain amount of money [directly or indirectly] to the officials responsible for awarding the tender (e.g. "go jesa sengwenyana" to the officials). This silent or unofficial practice of demanding kickbacks from tendering entities is apparently quite prevalent in Botswana even at ministerial level. The evidence [anecdotal] also indicates that there are several such local vernacular phrases used by corrupt government and private company officials to perpetuate corrupt practices.

The following are typical examples of such phrases:

- 'Diga sengwe' loosely translated in English meaning drop something. This phrase is associated with traffic officers conversing with culprits caught over-speeding and attempting to negotiate a reduced fine or a pardon. In fact, there are several such phrases associated with traffic officers e.g. ' $m p h a$ ' lunch/drink (meaning give me money for lunch or a drink) after being given a warning and not a traffic fine.

- 'Wa reng o kare ga o monna jaana, dira/diga sengwe' - meaning, why do you behave like you are not a real man, do something/drop or give me something. This phrase is commonly used at police road blocks when traffic offenders ask a police officer to pardon them for a traffic [minor] offence. The phrase is directed to a traffic offender who is negotiating to be given a warning as opposed to a fine. The phrase is used to solicit a bribe in place of a traffic fine.

- 'Bona rre yole' - this phrase is directed to a traffic offender who is attempting to negotiate with a police officer operating a traffic laser instrument, for a reduced fine. The phrase means 'see that man', the man being a police officer at a road block who is issuing traffic fines to traffic offenders caught by the officer operating the laser instrument. After 'seeing the man' the traffic offender pays the reduced fine which is not recorded in the government receipt book, and is later shared between the laser instrument operator and the traffic fine issuing officer. As a result the officers record some fines but do not record other fines which find their way into their pockets.

- 'A ko o thwaafale' - meaning 'please get serious' - the seriousness here indirectly means that the client/traffic offender should speak in pecuniary terms to be let off the hook. Similarly 'after getting serious' e.g. paying a bribe to the traffic officer [in case of traffic offence] the proceeds are shared by the officials involved in the transaction.

- 'Akanya sengwe' - this phrase means 'think of something' the phrase is used to ask the client to pay the service provider [government/private sector] money for a reduced fine or deflated price of a product/service. The ultimate effect is that regulations are circumvented for the financial benefit of the official assisting the 
client.

- $\quad T l a ~ k a ~ 2 '-$ this phrase is commonly used in both government and private sector organisations by officials asking a client to bring a certain amount of money depending on the cost of service/product they are seeking from government/private sector organisation. The phrase means 'come at/with two' which could mean that one should come at $02: 00 \mathrm{PM}$ or 14:00Hrs. However, the two or four in this case means either two/four hundred pula or two/four thousand pula, 2. depending on the cost of service/product under consideration.

- 'A o tlaa njesa senwgenyana?' - This phrase translated to English means 'Are you going to give me something [money] for my benefit?' When you ask for discount on the price of a product or service at a private organisation. Normally the practice is that discount is given to customers when they ask for it but in this case, the service provider giving the discount wants to be paid a bribe to give the client discount, making the whole process seem as though they were doing the client a favour. No bribe [sengwenyane] no discount.

The above phrases are all intended to obtain money from clients or the general public through unscrupulous means. Ultimately, the perpetrators of this practice find an opportunity [entrepreneurial] wherein bribes are solicited from clients on a daily basis, during office hours. The corrupt official(s) find bribe solicitation a tenderpreneuring opportunity. The practice eventually becomes a culture of the department in question before it afflicts the entire organisation/ministry. In the long run, the practice may spread to other organisations and ultimately become the culture of a nation/country to pay bribes before being provided with service.

In short, tenderpreneuring is generally used to describe someone masquerading as a legitimate businessperson, using political contacts to secure lucrative government contracts irrespective of whether they have been tendered for or not (Majawar, 2017; Chege, 2018).

This paper is a theoretical attempt to define the term 'tenderpreneuring'. The paper also theoretically attempts to examine the effects of tenderpreneuring through suppositions and or conjectures. The paper also makes an effort to make a comparison between 'tenderpreneuring' and the traditional form of tendering which follows best practice governance principles. An endeavor is also made to trace the roots of 'tenderpreneuring' and how 'tenderpreneuring' has the potential to negatively impact citizen economic empowerment. The paper further attempts to use the theory of accountability to demonstrate that where tendeperpreneuring is practiced, there are connotations of poor governance on the part of [government or private company] officers who award lucrative tenders to tenderpreneurs.

Accordingly, this paper is divided as follows; section 2 presents the research design and methodology adopted in this paper, while section 3 presents a discussion of the literature and theoretical framework is discussed in section 4. Consequences of tenderpreneuring are presented in section 5 . The paper ends with a summary and conclusion in section 6.

\section{Research Design \& Methodology}

This paper theoretically attempts to examine a 'buzzword' which has been used to describe a practice wherein the awarding of tenders both in the public and the private sector in some developing countries tends not to follow due process. As a result, the tenders are awarded to individuals and or companies having connections [political, familial or otherwise] within the cartels in government/private sector procurement world to be able to swing lucrative tenders their way and share the usually overpriced bill with the partners in crime after the payment of the project fees (Marjawar, 2017). As per the definitions of tenderpreneuring, possible corrupt practices are perpetuated through the lopsided awarding of lucrative government and or private contracts to cronies, relatives, concubines and or associates of people tasked with decision making authority in high offices in government and the private sector in developing countries, in particular South Africa, Kenya and Botswana.

Not much has been done by way of research in the area of tenderpreneuring. An extensive search on the internet for the definition of the word 'tendepreneur' indicates that there is a dearth of literature on this concept. In a way, this paper may be the first to examine the concept of 'tenderpreneuring' from an academic standpoint because most of the writings uncovered by the researchers are mainly opinion pieces on web pages and newspaper reports. This paper therefore adopts a theoretical approach by reviewing available literature on tenderpreneuring. The paper theoretically compares the definition of tenderpreneuring with the traditional tendering process and draws inferences/conclusions from the dissimilarities. An endeavour is also made to theoretically demonstrate how tenderpreneuring affects citizen economic empowerment. A further attempt is made by the researchers to theoretically demonstrate accountability issues and or lack thereof occasioned by tenderpreneuring. 


\subsection{Public \& Private Sector Employee Comments in Botswana}

The paper also draws from comments made by public and private sector employees who attended a short course on supervisory skills at the University of Botswana Centre for Continuing Education in 2017 and 2018. A total of eight such short courses were conducted during this period with an average of 25 participants per session. These short courses covered several professional development skills such as; team building, change management, staff motivation, delegation, coaching and mentoring, interpersonal skills, planning and decision making, performance management and corporate governance amongst others. Each session is given two hours wherein the facilitator interacts with the participants and discusses the respective issues pertaining to a specific development skill. During these sessions participants discussed various governance challenges in their respective organizations in group sessions of a minimum of four to five people per group. As such, one of the issues which was raised by participants during these eight sessions was the issue of how tendering procedures are continuously flouted in violation of laid down procedures governing tendering processes. Participants also made group presentations which were then discussed and conclusions drawn on how to address these challenges when they get back to their respective organizations e.g. stem the tide of tender corruption.

\section{Literature Review}

Owing to the dearth of literature on 'tenderpreneuring', this section attempts to discuss the traditional form of tendering compared to the 'tenderpreneuring' way of tendering. The section also attempts to unpack the root causes of 'tenderpreneuring' by examining citizen economic empowerment and how possibly, those responsible for awarding tenders may hide behind the veil of citizen economic empowerment to award tenders to tenderpreneurs.

\subsection{Tendering, the Traditional vs the Tenderpreneuring Way}

\subsubsection{Traditional Tendering Process (Construction Industry)}

According to Ballesteros-Pérez et al. (2012) as cited in Laryea (2013, p. 927) tendering/competitive bidding is "a transparent procurement method in which bids from competing contractors, suppliers, or vendors are invited by openly advertising the scope, specifications, and terms and conditions of the proposed contract as well as the criteria by which the bids will be evaluated." Intrinsically, tendering/bidding may be considered as a commercial, strategic, and accountability process (CIOB, 2009; Laryea, 2013). It is a business practice in which suppliers compete against one another for the right to a business opportunity (Laryea, 2013, p. 927). In construction, the rationale for tendering is to select a suitable contractor and establish a price (Hackett et al. 2007; Laryea, 2013). Researchers contend that construction tendering is not in any way different from tendering in other industries (Laryea, 2013). Chief amongst the features of tendering/bidding process is competition. In addition tendering is widely used and standard business practice internationally. Construction tendering consists of five types; open, selective, negotiation, term and serial tendering processes. According to Laryea (2013) selection of a tendering method is based on the type of construction work to be carried out. The normal processes followed for construction tendering are as follows: (1) tender advertisement or notice, (2) closing of the tender, (3) tender validity period, (4) pre-tender stage, (5) tender evaluation process (against set criteria) and (6) tender award phase.

It is also common practice that entities bidding/tendering for government or private project(s) to among others demonstrate competence in carrying out the work(s) they tendered for, capacity to carry out the work(s) tendered for and capability among others. In addition, project costs are computed based on prevailing market prices of goods and services. A mark up on the cost of the project is then added to arrive at the tender price of the project. Tenders competed not only on price but also on quality, time to complete the project, firm reputation and meeting or fulfilling the requirements of other relevant pieces of legislation that tenderers had to comply with. However, this practice seems no longer to be the practice owing to the advent of tenderpreneuring.

\subsubsection{Tenderpreneuring Process}

The following discussion is based on information garnered from comments/discussion with public/private sector employees who attended a short course on supervisory skills at the University of Botswana Centre for Continuing Education between 2017 and 2018. The discussion is also premised on definitions of tenderpreneuring from both Kenya and South Africa.

Under tenderpreneuring, the expertise it seems are the 'connections' the tenderpreneur has with greedy [government or private sector company] officials in high offices with sticky palms which have to be greased/oiled to win a tender. In tenderpreneuring, the officials [government or private sector company] responsible for awarding tenders, award the tender to their 'business partner' (the tenderpreneur) who submit the tender. The 
tenderpreneur is then awarded the over inflated tender to carry out the specific project e.g. building a road, hospital, maintenance of public equipment, supply of goods and services etc.

In order for the tenderpreneur to be paid for work done, an inspector is assigned to inspect the tenderpreneur's completed [substandard] work. A corrupt official [government or private sector company] inspector who is part of the syndicate, is assigned to conduct the inspection, in order to ensure that the tenderpreneur's work is certified as completed and meeting [supposedly] the expected standard [of the corrupt syndicate]. The corrupt [government or private sector company] inspector duly approves and issues an inspection certificate for the work done irrespective of defects and or any anomalies. The tenderpreneur gets paid on the strength of the inspection certificate issued by the corrupt inspector. After payment is made to the tenderpreneur, private arrangements are made to 'share the spoils' of the loot between the tenderpreneur, [government or private company] officials responsible for awarding tenders, inspectors and any other peripheral official who are part of the syndicate and played a role in facilitating this process of looting from public coffers or the private company.

This practice will be repeated in another cycle for as long as the formula for sharing the spoils is strictly adhered to. If, the formula is contravened along the process of sharing the spoils, normally there is a tendency to leak the corrupt activity of the syndicate by the aggrieved party who has not been favoured by the sharing formula. Since the aggrieved party has no recourse to the courts of law, they resort to spilling the beans or blowing cover on their shenanigans in the process incriminating themselves and the entire criminal syndicate. A dispute with regard to the sharing formula brings to life the old adage that, there is no honour among thieves!! However, disputes rarely arise resulting in perpetual looting of public coffers by greedy officials.

\subsubsection{The Root Cause of Tenderpreneuring}

According to Street (2013) the root cause of tenderpreneuring is poor regulation in the market which results in unscrupulous characters taking shortcuts by paying off bribes or facilitation fees to corrupt [government or private sector company] officials, instead of producing proper products, nurturing good brands and reputations, or investing in great employees. Street (2013) contends that tenderpreneuring is not unique to developing nations, but that it is also present in developed nations. The difference, according to the author between developed and developing nations, is the degree of safeguards which have been built into the economic system to limit the damage brought about by tenderpreneuring. In developing countries, the safeguards are weak while in the developed countries the safeguards are strong. In developing countries there is a tendency to avoid every opportunity to create consequences for corrupt procurement. Measures on anti-corruption are not strong because of lack of political will on the part of the leaders who tend to allow their supporters to loot from government coffers and are also beneficiaries of such theft. Political leaders tend to look away while their supporters help themselves to state resources apparently to allow them to amass wealth which will be used during future general elections. Clearly, this indicates that in developing countries, political leadership either participates in the looting of public coffers or turn a blind eye when the looters descend on government coffers, a situation akin to asking the foxes to guard the henhouse.

In the next sub-section an attempt will be made to explore how tenderpreneuring may impact citizen economic empowerment.

\subsubsection{Citizen Economic Empowerment and Tenderpreneuring}

According to the Human Development Report (UNDP 1993:1) as cited by Gergis (1999, p. 3) "development must be woven around people, not people around development - and it should empower individuals and groups, rather than dis-empower them". Citizen economic empowerment or empowerment, is a concept bourne out of the realization that economic development and modernization has not benefitted the poor (Gergis, 1999). The Collins Concise Dictionary defines the word empower as, "giving power to" or "enabling" "permit, or give authority to" someone.

According to Rappaport (1987, p. 121), “...empowerment conveys both a psychological sense of personal control or influence and a concern with actual social influence, political power, and legal rights". In South Africa, the Black Economic Empowerment Commission (BEEC) has defined Black Economic Empowerment as "an integrated and coherent socio-economic process, located in the context of national transformation that is aimed to redressing the imbalances of the past" [Enter- prise, 1999]. South Africa has a history of racial segregation which ended in 1994. Under this policy, blacks were denied to participate meaningfully in the economic development of their country. As such the BEEC policy was a deliberate effort to redress the imbalances of the past, by ensuring a broader and more meaningful citizen participation in the development process of the country so as to attain sustainable development, growth and prosperity. 
The goal of empowerment in this context is to aid individuals to improve the quality of their own lives and also share equitably in economic growth of their country. Economic growth dependent on grants and or donations and government subsidies is intrinsically unsustainable compared to unleashing people's creative abilities and productive energies to achieve sustainable growth and continuous growth in their living standards (Gergis, 1988).

According to Conger and Kanungo (1988) any real empowerment must be 'self-empowerment' with an internal urge to influence and control whereby individuals feel an enhancement of their abilities to control, influence or cope with their social or economic roles. Gergis $(1988$, p. 8$)$ argues that empowerment should bring closer those who hold power and those who are powerless and that it should move the powerless into positions of power and make those at the higher levels of power accept sharing power with them. The sharing of power between the powerless and holders of power creates difficult situations (Gergis, 1988). For instance, power holders tend to reduce empowerment in an attempt to manage power. Power in this context defined in terms of the power of wealth or property and the power of knowledge. Researchers contend that, in the developing world, 'the elite appropriate wealth for themselves by monopolizing power at the political level through dictatorship or one party rule and through corruption at the administrative level' (Gergis, 1988, p. 9). Clearly, this indicates that power holders will be more reluctant to give power to the powerless. As such, power holders may superficially concede power to the powerless so as to be able to manage them [powerless]. This strategy maintains the status quo and leaves the powerless disempowered whilst the power holders holding power.

In line with the foregoing discussion, tenderpreneuring seems to be a strategy employed by those holding economic power to constantly maintain the status quo. Under tenderpreneuring, tenderpreneurs with connections to government officials (administrative power) are corruptly awarded overinflated lucrative government tenders worth millions of dollars. After receiving payment for substandard work on the project, the tendepreneur shares this loot with the syndicate comprising of the several chain of command within the racket [government or private sector company] officials responsible for adjudicating over the tenders, inspectors and other peripheral officials who are part of the syndicate. This process is repeated over and over again when the next tender is awarded and will continue unabated for as long all members of the criminal syndicate are happy with the formula used for sharing the proceeds of corruption looted from government or private company coffers. Tenderpreneuring therefore perpetually empowers the corrupt syndicate in government who are tasked with adjudicating over [government or private sector company] tenders (administrative power). It also [tenderpreneuring] empowers them economically because they constantly siphon millions of dollars from government coffers or private companies through tenders. In a way, it is highly unlikely that the empowered may cede power to the disempowered because that implies losing administrative, political and economic power and possibly risking prosecution and jail term.

As such, tenderpreneuring tends to possibly defeat citizen economic empowerment to some extent.

\subsection{Theoretical Framework}

The definition of tendeperpreneuring has connotations of poor governance on the part of [government or private sector company] officers who award lucrative tenders to tenderpreneurs. In particular, public officers display lack of regard for accountability, ethics, responsibility, independence in the discharge of the responsibilities of their offices. The definition connotes that public officers connive with thieves (tenderpreneurs) to loot government/public coffers hiding behind the veil of tendering procedures. The definition insinuates dereliction of duty on the part of [government or private sector company] officers, incompetence, theft and outright thuggery perpetuated by greed and the lust for self-enrichment at the expense of the poor masses who have to bare the brunt of poor service delivery, poor economic empowerment, substandard public projects and abject poverty on the part of communities and ultimately nations.

The following sub-section attempts to draw inferences from the definition of tenderpreneuring in comparison with best practice corporate governance principles. Emphasis would be placed on poor accountability [as implied by the definition of tenderpreneuring practices by [government or private company] officers who award over inflated contracts to tenderpreneurs.

\subsection{Corporate Governance, Agency Theory \& Tenderpreneuring}

Researchers on corporate governance have proffered several definitions of corporate governance. For instance Nganga et al. (2003) defines it as the prevention of theft, while Shleifer and Vishny (1996), define it as the ways suppliers of finance to corporations assure themselves of getting a return on their investment, how they make sure that managers do not steal capital or invest in bad projects. In other words, corporate governance is "the mechanism through which outside investors are protected against expropriation by insiders" (Shleifer and Vishny, 1996). According to this definition, insiders include among others managers, major shareholders (individuals, 
other firms, family interests or governments) as well as large creditors such as banks. Outsiders include equity investors, providers of debt and minority shareholders who do not have any management roles but contribute capital towards the firm. In the context of tendering/bidding, officials responsible for adjudicating in the award of tenders are agents (insiders) while the electorate/shareholders [in the case of public/private sector companies] are the principals (outsiders).

As per Nganga et al. (2003) expropriation by insiders could take many forms such as outright theft of assets, transfer pricing, excessive executive compensation and diversion of funds to unsuitable projects that benefit one group of insiders.

The need for prevention of theft (Nganga et al., 2003) or putting in place mechanisms through which outside investors are protected against expropriation by insiders (Shleifer and Vishny, 1996) is brought about by the separation of ownership and control/agency theory (Berle and Means, 1932).

Jensen and Meckling (1976) define an agency relationship "as a contract under which one or more persons (the principal(s)) engage another person (the agent) to perform some service on their behalf, which involves delegating some decision making authority to the agent." Two problems arise in an agency relationship, when: (a) the desires or goals of the principal and agent conflict, and (b) it is difficult or expensive for the principal to verify what the agent is actually doing (information asymmetry). The former agency problem arises because of the assumptions that: first, the principal and agent have different risk appetite (e.g. different attitudes towards risk) (Eisenhardt 1989). Differences in risk appetite may result in different actions (Eisenhardt 1989); second, the principal and agent have different goals and interests. The third assumption is that, if both parties to the relationship are utility maximisers there is good reason to believe that the agent will not always act in the best interests of the principal (Jensen and Meckling 1976). Agency theory therefore seeks to resolve problems which can arise when the interests of the principal/agent are in conflict and when it is difficult or expensive for the principal to verify what the agent is doing presumably on his behalf.

The definition of tenderpreneuring indicates that agents [private sector company/government officials] acting on behalf of principals [the general public/shareholders] behave inappropriately by colluding with members of their syndicate(s) to contravene corporate/official bidding/tendering processes. This compares to a classic agency conflict (Berle \& Means, 1932) between managers (agents) and shareholders (principals) wherein managers as agents of shareholders (principals) can engage in self-serving behavior, which may destroy shareholder wealth. The destruction of shareholder wealth in this case is done through awarding tenders to unqualified tenderpreneurs who deliver/produce substandard work(s) or poor quality products and services. It [definition] also implies weak governance mechanisms which may safeguard against collusion by agents of tenderpreneurs who sit in committees tasked with the responsibility to adjudicate on the awarding of tenders. The definition also implies poor internal control mechanisms wherein agents of tenderpreneurs are able to sit in committees to flaunt procedures for awarding of tenders through the various stages starting from tender advertisement or notice, closing of the tender, tender validity period, pre-tender stage, tender evaluation process (against set criteria) and tender award phase. The definition also implies that theft happens with impunity in organisations and government departments. In addition it also implies that expropriation by insiders [company/government officials] such as outright theft of finances and diversion of funds to unqualified tenderpreneurs to benefit company/government officials is common occurrence.

Tenderpreneuring also implies lack of accountability on the part of agents [private sector company/government officials] to their principals because agents tend to repeat the unscrupulous awarding of tenders for as long as the formula for sharing the proceeds of their crime is strictly adhered to. Accountability can be seen as a relationship involving the "giving and demanding of reasons for conduct" (Roberts and Scapens, 1985, p. 447). "To be accountable is to be liable to present an account of, and answer for, the execution of responsibilities to those entrusting those responsibilities" (Gray and Jenkins, 1985, p. 138).

Accountability may also be defined as, 'the obligation to explain and justify conduct'. This implies a relationship between an actor, the accountor, and a forum, the account-holder, or accountee' (Pollitt 2003, p. 89). Mark (2006, p. 12) lists seven constituent elements which must be present in accountability for it to qualify as a social relation. According to Mark (2007) the following elements should be present in accountability; (i) existence of a relationship between an actor (accountor) and a forum (accountee); (ii) provisions of information by an an actor to some forum; (iii) explanation and justification of conduct by the actor and not propaganda, or the provision of information or instructions to the general public; (iv) direct and specific explanation to a specific forum and not random explanation to a general public (v) obligation on the part of the actor to come forward instead of being at liberty to provide any account whatsoever; (vi) existence of a possibility for debate and 
judgment by the forum, and an optional imposition of (informal) sanctions or rewards and not a monologue without engagement (vii) accessibility by the public of the account giving as opposed to purely internal, discrete informing. Accountability has four important questions which must be answered for it to hold; first, to whom is account to be rendered?; second, who should render account?; third, about what is account to be rendered?; and fourth, why does the actor feel compelled to render account? (Mark, 2006).

The long chain of delegation between principals and agents in public institutions creates an enabling environment for corrupt practices such as tenderpreneuring to thrive. For instance in public institutions (parliamentary democracies), the electrorate are the principals who delegatedecision making power to elected representatives. The elected representatives (parliamentarians) in turn delegate the majority of their authorities to the head of government (StrØm, 2000). The head of government (president) in turn delegates his authority to ministers who in turn delegate their authorities to civil servants (Magang \& Magang, 2016; StrØm, 2000). As a consequence, a long chain of delegation between the actual principals and agents creates accountability relationships between the electorate and parliamentarians (legislative branch); legislative branch and the executive branch (head of state); the head of state to different executive departments (ministers); the executive branch (ministers) and civil servants (Steffani, 1979 cited in StrØm, 2000, p. 267) who ultimately have the responsibility to implement public policy (StrØM, 2000).

The long chain of delegation therefore implies little to no demand for accountability on the part of the electorate. It also implies that there is high risk that the agents [public officials] may not faithfully pursue the interests of the principals because they are not directly answerable to them but rather are answerable to their political masters under whose portfolio the respective public institutions fall. As such, the long chain of delegation tends to create a conducive environment for tenderpreneuring to thrive in public institutions. In the same vein, the prevalence of tenderpreneuring in private and listed corporations may possibly be less than in non-governmental organisations because of the short chain of delegation and accountability relationships in these organizations. For instance in listed corporations, the chain of delegation is from shareholders to the board of directors and to management. In addition it is mandatory in many jurisdictions for listed corporations to hold an annual general meeting (AGM) wherein shareholders may have an opportunity to remove incompetent directors and senior management through a vote at annual general meetings or alternatively at an extraordinary general meeting (EGM) (Magang and Magang, 2016). However, these control mechanisms are not available to the principals [electorate] in governmental organisations. The only control mechanism available to the electorate is a general election which is held every four or five years.

\section{Consequences of Tenderpreneuring}

Tenderpreneuring has possible dire consequences on several fronts. First, tenderpreneuring may potentially rob the general public of financial resources which could otherwise be channeled to other worthy courses. Tenderpreneur's cost of the project is generally not based on the actual cost of delivering the project plus mark-up, but rather on the amount of money that the 'tenderpreneur' and his syndicate or cartel are willing to siphon out of governmentcoffers. It is at best a scheme devised by the syndicate to steal from the public (institutionalized corruption). On the face of it, the theft seems a legitimate payment for services rendered to government and or the public, complete with all the necessary legal documents, while in reality it is looting masqueraded as a legitimate transaction.

Second, tenderpreneurs hardly deliver projects which meet the required standard owing to the fact that they or their companies did not meet all the necessary qualifying criteria e.g. do not have expertise in the jobs/works they have tendered for. Clearly, an entity who does not have skill in a vocation may not be expected to produce work of any acceptable quality in that area. For instance, an entity whose only qualification and or expetise is a 'cellular phone with calling credit' may not be expected to produce acceptable quality infrastructure work like building roads, hospitals, schools etc. As a result, the public pays an overinflated price for substandard poor quality infrastructure work.

Third, tenderpreneuring puts the lives of users of public projects at a greater risk. For instance, corrupt government inspectors who are part of the tenderpreneuring syndicate are assigned to inspect works carried out by tenderpreneurs, wherein they issue certificates which indicate that work [completed] meets the required standard as opposed to condemning the work. As a result, a defective project is certified by corrupt inspectors as meeting the required standard and that other relevant documents such as certificate of occupancy be issued for the project and or facility in question to be put to use by the general public. The project in question could be a highway, a classroom, a hospital building etc, which are used by the general public on a daily basis. Over time, the defective project may collapse if it is a building resulting in injuries to the occupants and possibly dearth in the worst case 
scenario.

Fourth, tenderpreneuring is costly to the public in maintenance costs because the defective project (e.g. road, building etc) passed as meeting the required standard may require frequent maintenance to be done once the tenderpreneur contractor has handed the project over to the respective government department.

Fifth, tenderpreneuring stifles economic and social development because public coffers are perpetually looted by a few well connected individuals. Tenderpreneuring overstrains government budget and takes away resources from projects meant to benefit the poor. This results in government failing to allocate resources to important projects which may uplift the lives of the general public such as expenditure on education, health, policing, provision of safe drinking water, provision of electricity etc. It [tenderpreneuring] condemns the society to poverty at both personal and national level and robs them of their respect and dignity.

Sixth, in addition, to not meeting the required standard, tenderpreneuring projects are hardly completed on time and on budget owing to lack of expertise in project management skills of the tenderpreneur and skills in carrying out the project in question. In some instances, tenderpreneurs assign their tenders to companies skilled in the works they have tendered for, in a practice called 'fronting'. Although, this may result in good quality work produced by the assigned company, this is costly and deprives the general public of resources which could otherwise be allocated to other projects; because of the process of securing resources through a middleman. As an alternative, the procuring department could otherwise directly engage the skilled supplier and cut out the middleman (tenderpreneur).

\section{Conclusions \& Recommendations}

This paper has attempted to define tenderpreneuring using opinion pieces found from a search of the literature. The paper has also explored comments from public and private sector employees who attended refresher course(s) on supervisory skills at the University of Botswana. An attempt was made to demonstrate how tenderpreneuring is perpetuated in public/private organizations, what caused tenderpreneuring and its impact on citizen economic empowerment. The paper makes an attempt to demonstrate how tenderpreneuring impacts negatively on accountability in the public and private sector. An attempt is also made to demonstrate that the long chain of delegation between principals and agents in public institutions creates an enabling environment for corrupt practices such as tenderpreneuring to thrive. Finally, possible consequences of tenderpreneuring are explored. The findings from this paper may possibly highlight bad practices perpetuated in both the private sector/governmental organizations in the award of tenders in developing countries. The findings may also highlight the need to strengthen internal control mechanisms pertaining to tendering processes and the need to ensure that best practice corporate governance is adhered to at all times in the conduct of corporate transactions at both private sector/governmental organizations. The paper may also conscientise policy decision makers of the need to safeguard scarce public resources which are possibly looted by tenderpreneurs and their accomplices both in the private sector/governmental organizations in developing countries. In addition, the findings from the paper may possibly generate debates regarding tenderpreneuring.

This paper has several limitations; first, there is a dearth of literature on the concept of tenderpreneuring and as such the authors tended to rely mostly on opinion pieces from authors across three developing countries. Second, although the paper draws on comments from private/public sector organizations observations who attended several professional development training program/workshops over a two year period, more could be done by way of empirical research to investigate tenderpreneuring. Third, the paper tends to view tenderpreneuring from a negative lens owing to the limited literature in this area. Possibly, tenderpreneuring may not necessarily be as bad as it is being portrayed by the discussion from the paper. Finally, conclusions from this paper are mostly based on theoretical suppositions drawn from the literature and other concepts, hence the need to conduct empirical research to investigate tenderpreneuring.

\section{References}

Ballesteros-Pérez, P., González-Cruz, M. C., \& Cañavate-Grimal, A. (2012). Mathematical relationships between scoring parameters in capped tendering. Int. J. Project Manage., 30(7), 850-862.

Berle, A., \& Means, G. (1932). The Modern Corporation and Private Property. New York: Commerce Clearing House,

Bovens, M. (2006). Analysing and Assessing Public Accountability. A Conceptual Framework. European Governance Papers (EUROGOV) No. C-06-01. Retrieved from http://www.connex-network.org/eurogov/pdf/egp-connex-C-06-01.pdf

Chartered Institute of Building (CIOB). (2009). Code of estimating practice (7th ed.). Oxford: Wiley- Blackwell. 
Chege, N. (2018). How to spot young tenderpreneurs. Retrieved from https://www.nation.co.ke/oped/blogs/How-to-spot-young-tenderpreneurs/620-2965256-bburlc/index.html

Conger, J., \& Kanungo, R. (1988). The Empowerment Process: Integrating Theory and Practice. The Academy of Management Review, 13(3), 471-482. Retrieved from http://www.jstor.org/stable/258093

Eisenhardt, K. M. (1989). Agency Theory: An Assessment and Review. The Academy of Management Review, 14(1), 57-74.

Gergis, A. (1999). Citizen Economic Empowerment in Botswana: Concepts \& Principles. Working Paper No. 22. Botswana Institute of Development and Policy Analysis.

Gray, A., \& Jenkins, W.I. (1993). Codes of accountability in the new public sector. Accounting, Auditing \& Accountability Journal, 6(3), 52-67.

Jensen, M. C., \& Meckling, W. H. (1976). Theory of the firm: Managerial behavior, agency costs and ownership structure. Journal of Financial Economics, 3(4), 305-360

Laryea, S. (2013). Nature of Tender Review Meetings. Journal of Construction Engineering and Management, 139. 927-940.

Magang, T. I., \& Magang, V. G. (2016). Corporate Governance and Compliance in Botswana: Issues and Challenges. Journal of Research in Business, Economics and Management, 7(1), 1041-1061.

Marjawar, B. (2017). The Problem with Tenderpreneurship. Retrieved from https://www.linkedin.com/pulse/problem-tenderpreneurship-bob-marjawar/

McArdle, J. (1989). Community Development Tools of Trade. Community Quarterly, 16, 47-54.

Nganga, S., Jain, V., \& Artivor, M., (2003). Corporate Governance in Africa: A Survey of Publicly Listed Companies. London Business School.

Pier, L., \& Chairman, L. (2018). Tenderpreneur (also tenderpreneurship and tenderpreneurism). The Global Informality Project. Retrieved from https://www.academia.edu/37226490/Tenderpreneur_also_tenderpreneurship_and_tenderpreneurism_

Pollitt, C. (2003). The Essential Public Manager. London: Open University Press/McGraw- Hill.

Rappaport, J. (1987). Terms of empowerment/Examples of Prevention: Toward a Theory of Community Psychology. American Journal of Community Psychology, 15(2), 121-148. https://doi.org/10.1007/BF00919275

Schedler, A. (1999). Conceptualizing Accountability. In Andreas Schedler, Larry Diamond, Marc F. Plattner (Eds.), The Self-Restraining State: Power and Accountability in New Democracies. London: Lynne Rienner Publishers.

Shleifer, A., \& Vishny, R. W. (1997). A Survey of Corporate Governance. Journal of Finance, American Finance Association, 52(2), 737-783.

Street, B. (2013). Tenderpreneurs Vs $\quad$ Entrepreneurs. $\quad$ Retrieved from http://opinionkenya.com/public/?1349/Tenderpreneurs-Vs-Entrepreneurs

Strøm, K. (2000). Delegation and Accountability in Parliamentary Democracy. European Journal of Political Research, 37, 261-290. https://doi.org/10.1023/A:1007064803327

UNDP. (1993). Human Development Report. Oxford University Press.

\section{Note}

Note 1. A word blending the sounds and combining the meanings of two others.

Note 2. The exchange rate between the Botswana Pula (BWP) and American Dollar is equivalent to 1 USD = BWP10.90

\section{Copyrights}

Copyright for this article is retained by the author(s), with first publication rights granted to the journal.

This is an open-access article distributed under the terms and conditions of the Creative Commons Attribution license (http://creativecommons.org/licenses/by/4.0/). 